\title{
META-MODES OF LEARNING THAT SUPPORT AND INFLUENCE THE MILLENNIAL STUDENT'S HOLISTIC LEARNING EXPERIENCE AT AN ACADEMIC INSTITUTE IN SOUTH AFRICA
}

\author{
M. De Swardt \\ Department Informatics \\ Tshwane University of Technology \\ Pretoria, South Africa \\ e-mail: marlo.deswardt@gmail
}

\section{E. Hoque}

Graduate School of Business and Leadership

University of KwaZulu-Natal (Westville Campus)

Durban, South Africa

e-mail: hoque@ukzn.ac.za

\section{ABSTRACT}

Globally, academic institutes, which teach in diverse ways to a diverse generation, must ensure that learning is responsive, appropriate and supportive of cohorts in emerging and involving modes of learning. However, the pedagogy, processes and learning methods are of paramount importance for this diverse student generation. Therefore, in order to recognise subsequent cohorts for whom motivation and engagement in a holistic learning experience for millennial students could be maximised, is paramount. While it has been recognised that current learning practices may not address the holistic learning experience of the millennial student, the purpose of this study, through the adoption of the Student-Owned Learning-Engagement (SOLE) model, is to investigate and identify the confluence of meta-modes of learning that could support and influence the millennial student's holistic learning experience. In response to the needs of aspiring millennial learners, data were obtained from 69 students and 15 teachers by means of a selfadministrated questionnaire. A comparison was drawn between the theories that the millennials preferred meta-modes of learning and the modes of teaching that the teachers had adopted. Hence, this study offers strategies to improve the holistic experience of learning. This is performed in a manner that supports new empirical emerging and involving modes of learning for the millennial student.

Keywords: millennials, learning, learner, teacher, teaching

\section{INTRODUCTION}

In recent years, numerous studies have been carried out to profile the millennial generation. Mostly defined within a social and business context, the findings suggest that the millennials 
are a new breed of digitally wired, literate and connected individuals with clearly defined expectations (Taylor and Keeter 2010; Rasmus 2011; Holbeche 2015; Wang 2017). Taking cognisance of these expectations, this presents even greater potential educational changes and challenges for teachers to prepare these individuals for a clearly defined professional field (Cheng, Chow and Mok 2004; Bonner, Marbley and Howard-Hamilton 2011). The problem that arises, according to Roehl, Reddy and Shannon (2013), is that traditional approaches to teaching may not address the learning preferences of the millennial student; hence traditional approaches of teaching are no longer effective (Roehling, Kooi, Dykema and Quisenberry 2011; Phillips and Trainor 2014). Responding to the change, the challenge is to teach in a diverse manner to a diverse generation.

Other than the main purpose of representing or visualising the intended learning (Ferris 2012), the SOLE model, its nine elements of student activity or engagement and 42 meta-modes of learning capture the prerequisites for this study by closing the gap between the responses of learners and teachers to define a holistic learning experience. In analysing the quantitative data, a comparison is drawn between the millennials' preferred meta-modes of learning and the findings in the literature. The reasons that have led to the acceptance of a sound induction of meta-modes of learning lead to a conclusion that a number of confluences of meta-modes support and influence the millennial student's experience of learning positively. Given this causal relationship, a further comparison was drawn regarding the approaches of teaching at university level. Analysing these aspects enables a clear understanding between preferred approaches of learning by the millennials and how teachers teach. Based on the objective, this study offers strategies that could ensure a holistic experience of learning in a manner that supports emerging involving modes of learning that actively involve the millennial student.

\section{THE LITERATURE}

There is no categorical definition of the millennial generation (Luttrell and McGrath 2015). Similarly, there are no stereotypes because of the diversity that exists within this generation (Rainer and Rainer 2001). Since it is difficult to disentangle the differences, drawing upon a common understanding, the only orthodox cohesion that exists is that their birth dates range from 1980 to 2000 (Rainer and Rainer 2001; Eddy, Lyons and Schweitzer 2012; Espinoza and Ukleja 2016; Ryan 2016) and that the millennials are to become the most educated generation ever (Rainer and Rainer 2001; Taylor and Keeter 2010; Burstein 2013). This notion emanates from the research conducted by Singh, Bhandarker and Rai (2012) on a sample of 2,158 respondents, where the overall findings indicated that the millennials have an above average 
educational need. As reported by Taylor and Keeter (2010) in the Pew Research Centre report, in terms of education, the millennials aim high, with varying educational expectations (Roehling et al. 2011). Given the importance of expectations on an educational level, this inaugurates an argument that educational institutes are faced with the challenge to teach in diverse ways to a diverse generation (Atkinson and Burden 2011).

\section{Profiling the educational demographics of millennials}

Notwithstanding the generally accepted and used age criterion, other researchers and academics have profiled the millennials according to their demographic and psychographic background: education, personality and values (Bonner et al. 2011; Singh et al. 2012; Scardamalia 2015; Caraher 2015). To provide a holistic view, Table 1 is included, which contains a summary of the demographic and psychographic profile of approximately 50 million millennials, according to the Pew Research Centre report (Taylor and Keeter 2010).

Table 1: Demographic and psychographic profile of the Millennial

\begin{tabular}{|c|c|c|}
\hline Demographic background & Education & $\begin{array}{ll}\text { - } & \text { Smarter and more well-educated } \\
\text { - } & \text { Place more importance on being successful } \\
\text { - } & \text { Aim high } \\
\text { - } & \text { Study and work full time } \\
\text { - } & \text { Technological exceptionalism } \\
\end{array}$ \\
\hline \multirow[t]{2}{*}{ Psychographic background } & Personality & $\begin{array}{ll}\text { - } & \text { More tolerant than their elder generation } \\
\text { - } & \text { Open to change } \\
\text { - } & \text { Family matters most } \\
\text { - } & \text { Accustomed to meeting challenges } \\
\text { - } & \text { Find unique ways to express themselves } \\
\text { - } & \text { liberalism }\end{array}$ \\
\hline & Values & $\begin{array}{ll}- & \text { Respect } \\
\text { - } & \text { Honest and integrity } \\
\text { - } & \text { Trust } \\
\text { - } & \text { Teamwork }\end{array}$ \\
\hline
\end{tabular}

Given these communal characteristics and to provide a more holistic understanding, it is important to develop theoretical perceptual or collective views regarding how the millennial cohorts would respond to elements that might support and influence their learning experience. Thus, grounded in the theory, a thematic exploration of the literature reveals the following profiles of the millennials based on specific educational demographics:

- $\quad$ The millennials want feedback on demand (Coomes and Debard 2004).

- $\quad$ The millennial students are exposed to different ways of learning and since they are accustomed to meeting challenges, teachers must adjust their assessment process to evaluate more than just their learning (e.g., learners’ strengths and weaknesses) (Uskov, Howlett and Jain 2015). 
- According to McMahon and Pospisil (2005), a millennial student learning style is characterised by social constructivism and experiential learning that is based on a codesign approach of what has been learnt.

- Given that there are different learning environments, Hoidn (2017) argues that a deep learning approach is supported by a process of understanding and meaning that is found in personally relevant activities.

- Dickenson and Jaurez (2016) recommend that learning should provide relevance and value in the ability of a millennial student to perform specific work related activities.

- To provide the millennial student with support and guidance, and because they do respect authority, they will respond positively to learning where the subject is taught from the front of the classroom in a face-to-face presentation (Keup 2012).

- Howe and Strauss (2000) describe millennial students as cooperative team players. This is further supported by the finding of Coomes and DeBard (2004) that millennials mostly grew up working in groups and playing in teams.

- While it is acknowledged that the millennials are very focused on achieving personal goals (Slattery and Carlson 2005), according to Knowlton and Hagopian (2013), providing learning material in advance changes their perspective from a somewhat demanding or aggressive attitude of 'what is in it for me' to a subtler attitude of discovering 'what is in it for me'.

To contribute to the above-mentioned ideas, it is noted that Uskov et al. $(2015,142)$ point out that 'if a child can't learn the way we teach, maybe we should teach the way they learn'.

\section{Current pedagogical philosophies}

A variety of approaches to teaching improvements, which are generally associated with changing theories of learning, have emerged; this trend still continues today. Among the development of practices to improve teaching, strategies to improve learning in the 1970s were characterized by behavioural philosophies (Skinner 1965); in the 1980s, by cognitive philosophies (Bruer 1993); and in the 1990s, by social learning philosophies (Bruffee 1993). Currently, a sense of urgency to adapt to millennial learning preferences is emerging. Therefore, what could be considered to be an improved method of teaching is recognised as a major challenge as current pedagogical methods struggle to capture the attention of the millennial students (Roehl et al. 2013). According to Darling-Hammond (2006), this situation has arisen mainly because teachers lack knowledge about learners, how they learn, their needs, and the 
diversity among them; hence the inclusion of literature regarding the demographic, psychographic background and education demographic of millennials.

While there is a strong view that facilitating the curriculum rests upon teachers, which may be partially agreed upon, according to Middleton and Petitt (2010), it is important to look at learning from the students’ perspective in order to create valuable insights into the learning experience (Bernstein-Yamashiro and Noam 2013). However, drawing information from the Teaching and Learning International Survey (TALIS) (Vieluf, Kaplan, Klieme and Bayer 2012), a set of rich findings supports the contrary. Testing three classroom teaching practices, namely structuring, student orientation and enhanced activities, based on the research of Klieme, Pauli and Reusser (2009), revealed that supportive student-oriented classroom practice is mostly rated on the same level as structuring practices. However, 14 of the 23 mean factor scores $(60 \%)$ of the classroom teaching practices shows a decline in enhanced activities that drive the teaching practice of establishing a challenging context. Empirically, the reason for this might be a lack of knowledge about the millennial learners, because facilitating the curriculum continues to be teacher centric.

Notwithstanding the aforesaid shortcoming, Hidi and Harackiewicz $(2000,151)$ issue a reminder about the two explanations for unsatisfactory student academic performance, namely 'lack of ability and lack of effort'. While it has been established that millennials have an above average educational need, effort or motivation describe an inspirational relationship between the millennial and certain aspects of their mode of learning. However, while teachers are confronted with applying different modes of learning to motivate learners, teachers have no real substance that defines the method of teaching (Neufeld 2009). Therefore, given their general pedagogical knowledge, it is recommended to practise what they believe is the new way of teaching (Berliner and Calfee 2004) based on the concept of personal constructivism, as explained by Pritchard and Woollard (2010). Constructivism in this regard supports the following best practice perspectives as defined by McInernet and Liem (2008):

- $\quad$ Allow learners to construct their own understanding and knowledge.

- $\quad$ Link learning to prior learning knowledge.

- Introduce personal interaction with physical events in their daily lives.

- $\quad$ Allow for cooperative and collaborative learning.

- $\quad$ Establish after-school programmes for homework.

- $\quad$ Ensure that learners are actively engaged in actions that support learning.

- $\quad$ Establish a learner-centred classroom where teachers are the guide as opposed to teaching 
from the front of the class.

- Allow learners to think about the learning process, identify strategies to increase their learning, and self-monitor progress.

Emphasis on the former best practices has led to the belief that constructivism is a quick fix to learning and teaching improvement (Jones and Brader-Araje 2002). However, while this approach has failed to build on the needs of diverse student abilities and perspectives, teachers increasingly remain firm in the use of traditional teaching methods, mainly because of poor student results. According to the study conducted by Manson (2014), four out of five teachers reported using some (49\%), a lot (30\%) and all (2\%) of the teaching methods that are currently taught in the teaching programmes at universities. The practices that are mostly associated with the teaching programmes are: self-directed learning, self-reflecting learning, co-operative learning, problem-based learning, and adaptive instruction (Vieluf et al. 2012).

\section{The Student-Owned Learning-Engagement (SOLE) model}

According to Atkinson (2011), the purpose of the SOLE model is to develop practices and learning that are aligned with the expectations of the learners. A key attribute in this regard is that the model allows individual academics to reflect on their personal teaching practices, the specific needs of the discipline, and to draw on recommendations made in a professional development context (Ferris 2012). The underlying principle is that a representation or visualisation of the learning intent can be made available to students. Other than the given purpose, the application of the model in this study offers opportunities to observe learning practices that define the terms to support a particular facet of the teaching process and learning methods represented by each of the nine elements found in the SOLE model (Figure 1).

While it is suggested that learner experience and outcomes are largely influenced by the learner's perspectives, transparency in learning design remains a crucial element. This contemporary development has called for the ratification of new models of academic practice and new approaches to learning. To mention a few, the seven factor approach modelled by Jonas-Dwyer and Pospisil (2004), which is closely aligned with the detailed approach by Hung and Chen (2001) regarding e-learning design in the context of situated learning, results in six principles; and the Boud and Prosser (2002) framework that is structured around four areas, namely engagement of learners, acknowledgement of the learning context, learner challenges and the provision of learning practices. However, Ferris $(2012,5)$ argues that 'to design learning with the stress on the subject content, devoid of the learner experience is ineffective 


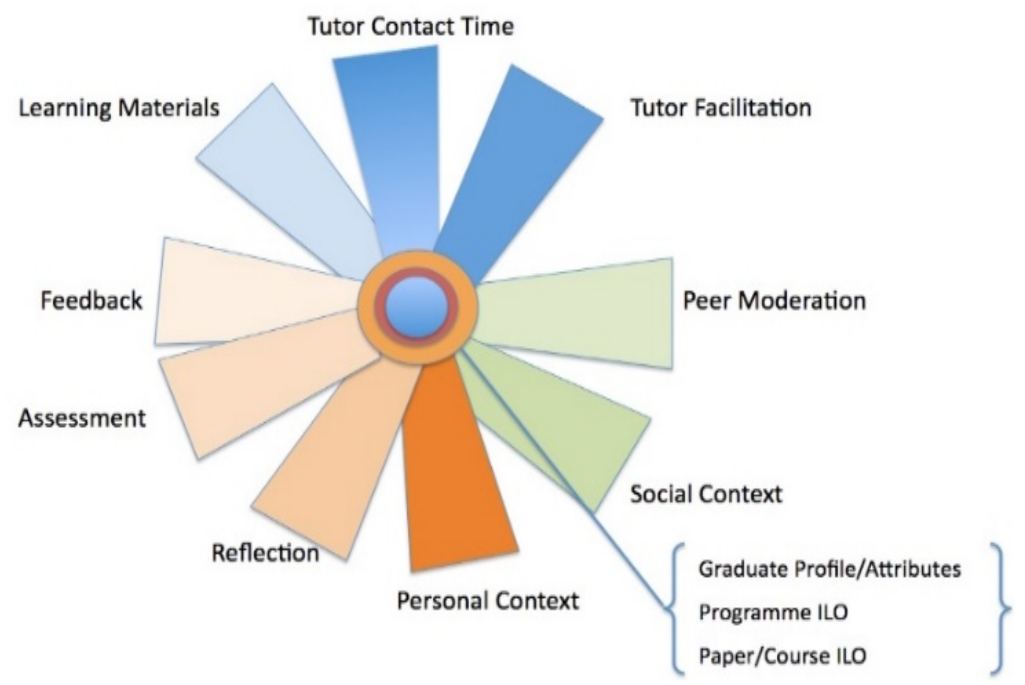

Figure 1: The SOLE model (Atkinson 2011)

and out of place'. Therefore, by incorporating existing theories (Hung and Chen 2001; Boud and Prosser 2001) and by placing the learner at the centre, the SOLE model and its nine elements of student activity or engagement captures the pre-requisites for effective learning design. Consequently, while there is a clear need for architecture of the future of the academic landscape to support a holistic learning experience, according to Atkinson (2011), the stated aims of the SOLE model are to:

- $\quad$ embody pedagogy, processes, and learning tools within an accessible and transparent model that could be shared by students and lecturers;

- $\quad$ embody best practices regarding integrated (Biggs and Tang 2011) learning experiences that could be shared by students and lecturers;

- $\quad$ produce a practical model that captures the perceptions to an alternative conceptualisation of learning;

- $\quad$ embrace the nature of student engagement to develop skills to profile and identify subsequent cohorts that could maximise the motivation and engagement towards a holistic learning experience (Atkinson and Burden 2011).

\section{RESEARCH METHODOLOGY}

Grounded in the philosophy of epistemology, this study applied a phenomenological research method as an underlying paradigm. The term phenomenology is an amalgam of the Greek words phenomenon and logos. According to Sokolowski (2000), this signifies the activities of giving an account of various phenomena regarding the various ways in which they appear. Given the tree example of Vagle (2016) as an explanation, this study is interested in the learning 
experience of millennial students rather than the qualitative properties of learning (e.g., outcomes of learning in terms of what is understood and remembered).

To fulfil this purpose, a self-administered questionnaire was developed and distributed to potential participants, mostly by hand delivery and some by means of email. Following a paper and pencil survey approach (Blumberg, Cooper and Schindler 2001) to collect the data, the questionnaire consisted of nine factors, including 42 meta-modes of learning which were ranked from 1 to 5 , where 1 is the highest preference, descending to 5, the lowest preference. Based on the research problem and that which needs to be measured, the units of analysis consisted of two groups, namely the student and teacher communities in an IT department, which was sampled from an IT faculty population at an academic institute in South Africa. The convenience sampling method was mainly based on the identification of participants among the students and teachers in class. The researcher visited academic classes to explain the questionnaire to the participants. To protect the rights of the participants, the participants were afforded the option to participate or not. While a good sample depends on accuracy and precision, this study however applied a non-probability convenience sampling strategy within the said sampling method. Taking into account the argument of Blumberg et al. (2001) that a convenience sample has no control over precision, Babbie (2005) explains that this sampling method is justified on the grounds of feasibility and is commonly used in a university research environment. The sample comprised 69 students and 15 teachers.

A quantitative methodology was adopted and the data were analysed statistically. The first step was to examine any confluences of meta-modes of learning that could support and influence the millennial student's holistic learning experience. The second step was to examine teachers' preferred methods of teaching, and thirdly, a comparison was drawn between the differences in opinion regarding recommendations for establishing an improved holistic experience of learning.

\section{DATA ANALYSIS}

Data were captured, coded and analysed using SPSS software package. Initially descriptive analyses were performed in order to summarise the characteristics of the sample. To search for a list of the variables, a codebook was created in SPSS, exported into Microsoft Excel, and further used to identify the variable codes, preferred ranking, count, means, and the percentage of each ranking. 


\section{RESULTS AND DISCUSSION}

To collect information on the sample, the statistical aim of the descriptive analysis was to obtain a measurement of each participant's age, the respective level of learning of the learners, and the number of years that the teachers had been in the teaching profession. Two students were excluded from the sample because their dates of birth did not correspond with the criteria defining a millennial. This affected the sample size negatively where the observed final total value of $\mathrm{N}=82$ was used for the purpose of analysing the modes of learning and teaching.

Table 2 furnishes a summary statement of the sample as a whole in order to facilitate making decisions regarding the strengths and applicability of the research population.

Table 2: Frequency and descriptive statistics

\begin{tabular}{|l|c|c|c|l|r|r|c|}
\hline \multirow{3}{*}{ Frequency } & \multicolumn{3}{|c|}{ Student academic year } & \multicolumn{4}{c|}{ Teacher teaching experience } \\
\cline { 2 - 8 } & Frequency & $\%$ & $\begin{array}{c}\text { Cumulative } \\
\text { \% }\end{array}$ & & Frequency & \% & $\begin{array}{c}\text { Cumulative } \\
\%\end{array}$ \\
\hline \multirow{2}{*}{$\begin{array}{l}\text { 1st Year } \\
\text { 2nd Year } \\
\text { 3rd Year } \\
\text { 4th years } \\
\text { Total }\end{array}$} & 15 & 22.4 & 22.4 & 1 Year & 1 & 6.7 & 6.7 \\
\cline { 2 - 8 } & 19 & 28.4 & 50.7 & 2 Years & 3 & 20.0 & 26.7 \\
\cline { 2 - 8 } & 16 & 23.9 & 74.6 & 3 Years & 3 & 20.0 & 46.7 \\
\hline
\end{tabular}

\begin{tabular}{|c|l|c|c|c|c|}
\hline \multicolumn{2}{|l|}{ Descriptive } & N & Min & Max & Mean \\
\hline \multirow{4}{*}{ Learners } & Academic year & 67 & 1 & 4 & 2.52 \\
\cline { 2 - 6 } & Birth Date & 67 & 1981 & 1998 & 1993 \\
\cline { 2 - 6 } & Valid N (listwise) & 67 & & & \\
\hline \multirow{3}{*}{ Teachers } & Birth Date & 15 & 1955 & 1997 & 1979 \\
\cline { 2 - 6 } & Experience & 15 & 1 & 4 & 3.2 \\
\cline { 2 - 6 } & Valid N (listwise) & 15 & & & \\
\hline
\end{tabular}

Considering the participant details (frequency, shape and spread), the results were contextualised rather than establishing patterns or relationships within the data. An analysis of the student academic year indicates an even spread of first and fourth year students following a frequency allocation of 15 and 19 participants respectively. The high result of 53.3 per cent for teacher teaching experience, with an established mean of 3.2 teaching years of experience, is a positive indication of the level of teaching experience. However, while it could be argued that the results of more experienced teachers could have different results, Rich (2010) reminds us that the impact of experience is stronger during the first few years of teaching, after which the marginal returns diminish. Hence, 'more is better' is a questionable notion, given the findings of Rich (2010).

The ratio of 67 students to 15 teachers is further validated where classes at the university currently have a ratio of one teacher for every 50 students. Furthermore, it is assumed that in 
the event where teachers share the same birth date as millennials, thus sharing common characteristics with the students, the results may address only what is considered to be a millennial perspective. Although the former extraction could exert a negative impact on the results, the pragmatism in this case is the verification and confirmation that the descriptive mean date of birth for the teachers is 1979 (generation X), and for the students, 1993 (generation Y millennial). Overall, the data obtained were normally distributed and therefore acceptable and suitable for further statistical analysis and reporting.

To search for a list of the variables, a codebook was created in SPSS. While Fielding and Gilbert (2003) argue that it is a useful tool used to identify the variables, the codebook was used to identify the variable labels, preferred ranking, count and percentage of each ranking. Once a total percentage to define each variable with the highest preferred ranking (1) was derived, the results were further compared against the means of the 42 variables. In this case, however, by calculating the mean of a grouped variable, the selected mean represented the variable with the lowest preferred rankings (1) as the preferred learning and teaching modes. The main reason for choosing this specific ranking order is to simplify the understanding, by referring to the socalled number one (1) preference.

Table 3 is included to establish the lowest score for each variable given the condition that 1 = highest preference.

Table 3: The means for modes of learning and teaching for each variable

\begin{tabular}{|c|c|c|c|c|}
\hline \multicolumn{5}{|c|}{ Students } \\
\hline Variable & Variable Code & Modes of learning & Mean & Std. Deviation \\
\hline Feedback & $\mathrm{Fd}$ & In class feedback & 1.99 & 1.297 \\
\hline Assessment & $\mathrm{Aa}$ & Assignments & 1.88 & 1.187 \\
\hline Reflection & $\mathrm{Rb}$ & Formative assessments & 3.24 & 1.207 \\
\hline Personal Context & Pcc & Reference real-world examples & 2.57 & 1.282 \\
\hline Social Context & Sca & $\begin{array}{l}\text { Based learning on potential career } \\
\text { opportunities }\end{array}$ & 2.42 & 1.587 \\
\hline Peer Moderation & Pma & Use brainstorm techniques in class & 1.69 & 1.062 \\
\hline Tutor Facilitation & Tfa & Spend most of time in front of class & 2 & 1.243 \\
\hline Tutor Time & Tta & Balance of time towards face-to-face presence & 1.81 & 0.988 \\
\hline Learning Material & Lme & Provide learning material in advance & 1.79 & 1.175 \\
\hline Valid N & & & 67 & \\
\hline \multicolumn{5}{|c|}{ Teachers } \\
\hline Variable & Variable Code & Modes of Teaching & Mean & Std. Deviation \\
\hline Feedback & $\mathrm{Fb}$ & Feedback briefing sessions & 2.67 & 1.424 \\
\hline Assessment & $\mathrm{Aa}$ & Assignments & 2.33 & 1.496 \\
\hline Reflection & $\mathrm{Rb}$ & Formative assessments & 2.73 & 1.438 \\
\hline Personal Context & Pcc & Reference real-world examples & 2.87 & 1.457 \\
\hline Social Context & Sce & $\begin{array}{l}\text { Common environment for sharing shared } \\
\text { perspectives }\end{array}$ & 2.27 & 1.242 \\
\hline Peer Moderation & $\mathrm{Pmb}$ & Students read and review each other's work & 2.13 & 1.552 \\
\hline Tutor Facilitation & Tfa & Spend most of time in front of class & 1.87 & 0.99 \\
\hline Tutor Time & Tta & Balance of time towards face-to-face presence & 1.87 & 0.743 \\
\hline Learning Material & Lmd & Cooperation in creating learning material & 2.2 & 1.506 \\
\hline Valid N & & & 15 & \\
\hline
\end{tabular}


The results highlighted in colour in Table 3 indicate that there is a mutual acceptance of modes of learning between student and teacher preferences. However, four of the nine variables (44\%) reflect the opposite, where the teaching modes that teachers employ do not directly correspond with that which is considered to be a holistic experience of learning for the millennial student. However, realising that the remaining scales between 2, 3 and 4 could influence the mean results, Table 4 includes a total percentage to define each of the highest preferred ranking (1) variables as a more reliable result for further analysis.

Table 4: Total percentage of each highest preferred ranking (1)

\begin{tabular}{|l|c|c|c|c|c|c|c|c|}
\cline { 2 - 9 } \multicolumn{1}{c|}{} & \multicolumn{4}{c|}{ Teachers } & \multicolumn{4}{c|}{ Students } \\
\hline Variables & $\begin{array}{c}\mathbf{V} \\
\text { Code }\end{array}$ & $\begin{array}{c}\% \\
\text { Result }\end{array}$ & $\begin{array}{c}\text { V } \\
\text { Code }\end{array}$ & $\begin{array}{c}\text { Mean } \\
\text { Result }\end{array}$ & $\begin{array}{c}\text { V } \\
\text { Code }\end{array}$ & $\begin{array}{c}\text { \% } \\
\text { Result }\end{array}$ & $\begin{array}{c}\text { V } \\
\text { Code }\end{array}$ & $\begin{array}{c}\text { Mean } \\
\text { Result }\end{array}$ \\
\hline Feedback & $\mathrm{Fe}$ & 26.70 & $\mathrm{Fb}$ & 2.67 & $\mathrm{Fd}$ & 50.70 & $\mathrm{Fd}$ & 1.99 \\
\hline Assessment & $\mathrm{Aa}$ & 46.70 & $\mathrm{Aa}$ & 2.33 & $\mathrm{Aa}$ & 56.70 & $\mathrm{Aa}$ & 1.88 \\
\hline Reflection & $\mathrm{Ra}$ & 46.70 & $\mathrm{Rb}$ & 2.73 & $\mathrm{Re}$ & 29.90 & $\mathrm{Rb}$ & 3.24 \\
\hline Personal Context & $\mathrm{Pca}$ & 26.70 & $\mathrm{Pcc}$ & 2.87 & $\mathrm{Pca}$ & 28.40 & $\mathrm{Pcc}$ & 2.57 \\
\hline Social Context & $\mathrm{Sca}$ & 33.30 & $\mathrm{Sce}$ & 2.27 & Sca & 46.30 & Sca & 2.42 \\
\hline \hline Peer Moderation & $\mathrm{Pma}$ & 46.70 & $\mathrm{Pmb}$ & 2.13 & $\mathrm{Pma}$ & 62.70 & Pma & 1.69 \\
\hline Tutor Facilitation & $\mathrm{Tfa}$ & 46.70 & $\mathrm{Tfa}$ & 1.87 & $\mathrm{Tfa}$ & 53.70 & $\mathrm{Tfa}$ & 2 \\
\hline Tutor Contract Time & $\mathrm{Ttd}$ & 40.00 & $\mathrm{Tta}$ & 1.87 & $\mathrm{Tta}$ & 50.70 & $\mathrm{Tta}$ & 1.81 \\
\hline Learning Material & $\mathrm{Lmd}$ & 46.70 & $\mathrm{Lmd}$ & 2.2 & $\mathrm{Lme}$ & 61.20 & $\mathrm{Lme}$ & 1.79 \\
\hline
\end{tabular}

A cross correlational check between the percentages of the highest preferred ranked variable (Table 4) and the means of the grouped variables (Table 3) were performed. It is reported that only 'Assessment and Tutor Facilitation' are accepted as the manner in which teachers teach, with respect to how millennials learn. It must be noted that where there is a direct correlation between the variables, factors of the means were introduced into the equation to verify the correlational decision. To explain, 'Social Context' has a correlational percentage which identifies the variable 'link learning to prior learning activities' (Sca) as an acceptable learning and teaching preference. However, the mean variable for the teacher's preference indicates 'reflection of personal relevance activities' (Sce) as the preferred method of teaching. Based on the mean and percentage results, nine of the SOLE seven elements (77\%) do not correspond with the millennial's educational demographics.

While the requirements of students and the tools used in teaching them cannot be ignored, some of the older methods remained somewhat relevant and are still considered to be good practices. Considering the reality of the aforesaid and the results of this study, using assignments for assessment purposes aligns the learning process with that which involves 
specific content and skill. The teachers in this study agree with the notion that acquiring content knowledge has been identified as a learning mode for millennial students (Fisher 2013). Therefore, assignments remain important to challenge and provide millennial students with the clarity required regarding the learning outcomes (Dougherty 2012). Grouping within the same category is the archetype mode of learning which describes the practise of teaching face-to-face from the front of the class (Myhill, Jones and Hopper 2006). In this study, both meta-modes of learning and teaching (assignments and face-to-face) in support of the given elements (assessment and tutor facilitation) render these learning and teaching modes effective as illustrated in Table 5.

However, based on the literature findings and the study results, in general, the perceived pedagogical methods of teaching do not correspond with the meta-modes of learning that might support and influence the millennial student's learning experience. Given the nine elements, the areas of concern that were identified are student feedback, reflection, personal context, social context, peer moderation, tutor contract time, and to provide learning material in advance to support domain knowledge acquisition. Table 5 is included for further explanation.

Table 5: Comparison of study results

\begin{tabular}{|c|c|c|}
\hline $\begin{array}{l}\text { SOLE } 9 \text { Elements } \\
\text { (Variables) }\end{array}$ & Teaching & Learning \\
\hline Feedback & Special feedback groups & In class feedback \\
\hline Assessment & Assignments & Assignments \\
\hline Reflection & Develop portfolio inclusive of key artefacts & $\begin{array}{l}\text { Share views and experience based } \\
\text { on what has been learnt }\end{array}$ \\
\hline Personal Context & Reflection on personal relevant activities & $\begin{array}{l}\text { Link learning to prior learning } \\
\text { activities }\end{array}$ \\
\hline Social Context & $\begin{array}{l}\text { Common environment for sharing shared } \\
\text { ideas }\end{array}$ & $\begin{array}{l}\text { Base learning on potential career } \\
\text { opportunities }\end{array}$ \\
\hline Peer Moderation & Students read and review each other's work & Use brainstorming techniques in class \\
\hline Tutor Facilitation & Spend most of the time in front of the class & $\begin{array}{l}\text { Spend most of the time in front of the } \\
\text { class }\end{array}$ \\
\hline Tutor Contract Time & $\begin{array}{l}\text { Timetables needs to be adhered to all the } \\
\text { time }\end{array}$ & $\begin{array}{l}\text { Balance time towards face-to-face } \\
\text { presence }\end{array}$ \\
\hline Learning Material & Remain firm within the curriculum design & Provide learning material in advance \\
\hline
\end{tabular}

In the light of the literature findings on the demographic and psychographic background, that is, education, personality and values of millennials, it should be noted that some of the preferred modes of learning stem from the demographic and psychographic background. The following information is extracted to illustrate this:

- Millennials base learning on potential career opportunities which might relate to the millennials placing greater importance on being successful and because they work and study full time. 
- Millennials prefer a learning mode where the teacher spends most of the time in front of the class with a face-to-face presence, which may relate to the values of trust, teamwork, and most probably family matters, most of which are comforting.

- The use of brainstorming techniques may relate to technological exceptionalism and the learners being accustomed to meeting challenges.

While the literature provided specific education demographics of the millennial student and best practices of pedagogic philosophies, the results indicated that many of the best practices that were defined by McInernet and Liem (2008) are misaligned. For example, while the theory indicates after-school homework as a best practice, the meta-mode of learning to provide homework that will allow time for contextualisation was scored as the less preferred method. Another key example is the meta-mode of learning that defines the element tutor facilitation. The best-practice perspective advanced by McInernet and Liem (2008) that teachers should establish a learner-centred classroom where teachers are the guide as opposed to teaching from the front of the class, contradicts the finding where both learners and teachers prefer tutor facilitation that is based on teaching from the front of the class. Notwithstanding this, according to Biggs and Tang (2011), an important aspect of effective teaching is the reflecting practice using transformation reflection. Teachers must reflect on their teaching and adapt sound theory of teaching and learning in order to improve the holistic learning experience of the millennial student.

\section{RECOMMENDATIONS}

Given the results, the educational system of teaching practices and perceived learning modes are disconnected. This may be a result of teachers not knowing the preferred modes of learning for millennial students or teachers know the modes of learning but prefer the older orthodox methods of teaching based on experience. However, as this study uncovers the unknown, to improve the holistic learning experience of the millennial student, it is recommended that teachers adopt the following meta-modes of learning in order to improve teaching strategies:

- To provide content knowledge, as part of the assessment process, assignments remain important to challenge and provide millennial students with the clarity regarding the learning outcomes.

- While digital learning environments have proved to offer several advantages, in this case as with many others, the traditional face-to-face method of teaching and learning creates 
a dynamic relationship shared between teacher, student and fellow students.

- Since the millennials were brought up to receive constant feedback whenever they want it, teachers must provide in-class feedback as opposed to applying a method of feedback groups.

- It is necessary to share views and experiences to create a co-design approach of that which has been learnt.

- $\quad$ Teachers must encourage learners to link learning to prior learning activities to support the process of understanding and meaning found in the relative personal activities of the millennial student.

- $\quad$ Learning must be based on potential career opportunities to explain and clarify work related activities that will provide relevance and value for the future of the student.

- $\quad$ Brainstorming techniques must be used in class as a means to establish work groups in order to improve social interaction.

- $\quad$ Time must be balanced between face-to-face presence and other modes of teaching because millennials do respect authority.

- Learning material must be provided in advance in order to influence the millennial perspective towards a change in attitude that brings about acceptance of achieving a specific goal.

Where the learning and teaching modes are reported to be prejudiced, the findings and results clearly indicated that it is not necessary to abandon all traditional pedagogical learning and teaching philosophies. An important finding, however, is that the improved teaching strategies could encourage teachers to adopt some of the teaching approaches that would most appeal to the millennial students. Contributing to the body of knowledge, in this approach, the modes of learning impacting on teaching and learning could create a greater awareness of student needs and learning styles, teaching styles, and pedagogical design to advance student motivation.

The limitations of this study, however, must be mentioned. While co-creating learning communities may be supported, it has to be noted that teachers as professionals are responsible for pedagogy and not the students; hence the drive for a learning process based on scientific teaching knowledge and methodology. Therefore, what might be a possible concern is the balance between student cognitive ability to cope with discipline specific requirements for achievement and a student's perspective about a holistic learning experience towards achievement. However, given the aforesaid contention, and while it might be considered to exert an impact on learning experience in general, cognitive ability does not fall into the scope of this study. 


\section{CONCLUSION}

Teaching is a highly skilled and challenging profession in which teachers are expected to teach the whole person, not just the cognitive mind. Globally, this has caused institutions to be challenged by the need to provide increasingly personalised learning experience for increasingly diverse cohorts of students. The notion of a 'holistic learning experience' implies that there is something else that needs to be incorporated into the learning practice. Therefore, this study applied the SOLE model to draw upon the causal relationship that a number of confluences of meta-modes of learning support and influence the learning experience of the millennial student positively. Illustrating the opportunities that exist in the application of the SOLE model, nine elements based on the scope of the research were identified. The subsequent phase of this study will be to empirically apply and test the modes of learning by applying elements of learning in order to implement specific emerging modes of learning that include the involvement of the learner. While some of the recommended practices do constitute part of the informal teaching practices, this study offers teachers with direct evidence of the results of their efforts, resulting in clear and precise improvements to advance the learning experience of the millennial student.

\section{REFERENCES}

Atkinson, S. 2011. Embodied and embedded theory in practice. The Student-Owned LearningEngagement (SOLE) model. International Review of Research in Open and Distance Learning 12(2).

Atkinson, S. and K. Burden. 2011. Learning design for Student-Owned Learner-Engagement. $27^{\text {th }}$ Annual Conference on Distance Teaching \& Learning.

Babbie, E. 2005. The basics of social research. $3^{\text {rd }}$ Edition. California: Thomson Wadsworth.

Berliner, D. C. and R. C. Calfee. (Eds.). 2004. Handbook of educational psychology. New York: Routledge.

Bernstein-Yamashiro, B. and G. G. Noam. 2013. Teacher-student relationship. Towards personalized education. California: Springer.

Biggs, J. and C. Tang. 2011. Teaching for quality learning at University. $4^{\text {th }}$ Edition. Berkshire: McGraw-Hill.

Blumberg, B. F., D. R. Cooper and P. S. Schindler. 2001. Business research methods. $4^{\text {th }}$ Edition. Berkshire: McGraw-Hill Education.

Bonner, F. A., A. F. Marbley and M. F. Howard-Hamilton. (Eds.). 2011. Diverse millennial students in college. Implications for faculty and student affairs. Sterling: Stylus Publishing.

Boud, D. and M. Prosser. 2002. Appraising new technologies for learning. A framework for development. Educational Media International 39(3): 237.

Bruer, J. T. 1993. Schools of thought. A science of learning in the classroom. Cambridge: MIT Press.

Bruffee, K. A. 1993. Collaboration learning. Interdependence and the authority of knowledge. Baltimore: The Johns Hopkins University Press. 
Burstein, D. D. 2013. Fast future. How the millennial generation is shaping our world. Massachusetts: Beacon Press.

Caraher, L. 2015. Millennials and management. The essential guide to making it work at work. Brookline: Bibliomotion, Inc.

Cheng, Y. C., K. W. Cow and M. C. Mok. (Eds.). 2004. Reform of teacher education in the Asia-Pacific in the new millennium. Trend and challenges. Norwell: Kluwer Academic Publishers.

Cooms, M. D. and R. DeBard. (Eds.). 2004. Serving the millennial student. San Francisco: Jossey-Bass.

Darling-Hammond, L. 2006. Constructing 21st-Century teacher education. Journal of Teacher Education 57(3): 300-314.

Dickenson, P. and J. J. Jaurez. (Eds.). 2016. Increasing productivity and efficiency in online teaching. Hershey: IGI Global.

Dougherty, E. 2012. Assignments matter. Making the connection that help students meet standards. Virginia: ASCD.

Eddy, S., S. T. Lyons and L. Schweitzer. (Eds.). 2012. Managing the new workforce. International perspectives on the millennial generation. Massachusetts: Edward Elgar Publishing.

Espinoza, C. and M. Ukleja. 2016. Managing the millennials. Discover the core competencies for managing today's workforce. $2^{\text {nd }}$ Edition. New Jersey: John Wiley \& Sons.

Ferris, S. P. 2012. Teaching, learning, and the Net Generation. Concepts and tools for reaching digital learners. Hersey: IGI Global.

Fielding, J. L. and N. Gilbert. 2003. Understanding social statistics. London: SAGE.

Fisher, M. 2013. Digital learning strategies. How do I assign and assess $21^{\text {st }}$ Century work. Massachusetts: ASCD.

Hidi, S. and J. M. Harackiewicz. 2000. Motivating the academically unmotivated. A critical issue for the $21^{\text {st }}$ Century. Review of Educational Research 70(2): 151-179.

Hoidn, S. 2017. Student-centred learning environments in higher education. New York: Palgrave Macmillan.

Holbeche, L. 2015. The agile organization. How to build an innovative, sustainable and resilient business. Philadelphia: Kogan.

Howe, N. and W. Strauss. 2000. Millennials rising: The next great generation. New York: Vintage Books.

Hung, D. W. L. and D. T. Chen. 2001. Thought and learning from the communities of practice perspective: Implications for the design of Web-Based E-Learning. Educational Media International 38(1): 3-12.

Jonas-Dwyer, D. and R. Pospisil. 2004. The millennial effect. Implications for academic development. HERDSA $27^{\text {th }}$ Annual Conference Proceedings, 194-205.

Jones, M. G. and L. Brader-Araje. 2002. The impact of constructivism on education. Language, discourse and meaning. American Communication Journal 5(3).

Keup, J. R. 2012. Peer leadership in higher education. New direction for higher education. New York: Jossey-Bass.

Klieme, E., C. Pauli and K. Reusser. (Eds.). 2009. The power of video studies in investigating teaching and learning in the classroom. Munster: Waxmann.

Knowlton, D. S. and K. J. Hagopian. (Eds.). 2013. From entitlement to engagement. Affirming millennial student's egos in the higher education classroom. San-Francisco: Jossey-Bass.

Luttrell, R. and K. McGrath. 2015. The millennial mindset. Unravelling fact from fiction. London: Rowman and Littlefield.

Manson, K. O. 2014. Preparing for the classroom. What teachers really think about teacher education. London: Rowman \& Littlefield. 
McInernet, D. M. and A. D. Liem. (Eds.). 2008. Teaching and learning. International best practices. North Carolina: IAP.

McMahon, M. and R. Pospisil. 2005. Laptops for a digital lifestyle. Millennial students and wireless mobile technologies. ASCILITE 2005 Balance, Fidelity, Mobility. Maintaining the momentum, 421-431.

Middleton, K. E. and E. A. Petitt. 2010. Simply the best. 29 things students say the best teachers do around relationships. Indiana: AuthorHouse.

Myhill, D., S. Jones and R. Hopper. 2006. Talking, listening, learning. Effective talk in the primary classroom. England: Open University Press.

Neufeld, J. 2009. Redefining teacher development. New York: Routledge.

Phillips, C. R. and J. E. Trainor. 2014. Millennial students and the flipped classroom. ASBBS Annual Conference 21(1): 519-530.

Pritchard, A. and J. Woollard. 2010. Psychology in the classroom. Constructivism and social learning. New York: Routledge.

Rainer, T. S. and J. W. Rainer. 2011. The millennials. Connecting to America's largest generation. Tennessee: B \& H Publishing Group.

Rasmus, D. W. 2011. Management by design. Applying design principles to work experience. New Jersey: John Wiley \& Sons.

Rich, J. K. 2010. The impact of teacher experience. Examining the evidence and policy implications. National Centre of Analysis of Longitudinal Data in Education, Brief 11.

Roehl, A., S. L. Reddy and G. J. Shannon. 2013. The flipped classroom. An opportunity to engage millennial students through active learning strategies. Journal of Family \& Consumer Sciences 105(2): 44-49.

Roehling, P.V., T. L. Vander Kooi, S. Dykema, B. Quisenberry and C. Vandlen. 2011. Engaging the millennial generation in class discussions. College Teaching 59(1): 1-6.

Ryan, L. 2016. The visual imperative. Creating a visual culture of data discovery. Cambridge. Elsevier.

Scardamalia, R. L. 2015. Millennials in America. New York: Berman Press.

Singh, P., A. Bhandarker and S. Rai. 2012. Millennials and the workplace. Challenges for architecting the organization of tomorrow. New Delhi: SAGE.

Skinner, B. F. 1965. Science and human behaviour. New York: Free Press.

Sokolowski, R. 2000. Introduction to phenomenology. Cambridge: Cambridge University Press.

Slattery, J. M. and J. F. Carlson. 2005. Preparing and effective syllabus. Current best practices. College Teaching 53(4): 159-164.

Taylor, P. and S. Keeter. (Eds.). 2010. Millennials. A portrait of generation next. Pew Research Center Report. http://www.pewsocialtrends.org/files/2010/10/millennials-confident-connected-open-tochange.pdf (Accessed 04/01/2017).

Uskov, V., R. J. Howlett and L. C. Jain. (Eds.). 2015. Smart education and smart e-learning. New York: Springer.

Vagle, M. D. 2016. Crafting phenomenological research. New York: Routledge.

Vieluf, S., D. Kaplan, E. Klieme and S. Bayer. 2012. Teaching practices and pedagogical innovation. Evidence from TALIS. Paris: OECD Publishing.

Wang, V. C. X. 2017. Encyclopedia of strategic leadership and management. Hersey: IGI Global. 